\section{E-LOGOS}

ELECTRONIC JOURNAL FOR PHILOSOPHY ISSN 1211-0442

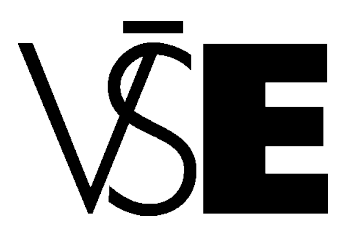

University of Economics

Prague

\title{
Problémy kauzality ve fyzice i mimo ni Planckovým pohledem
}

\author{
Veronika Nováková
}

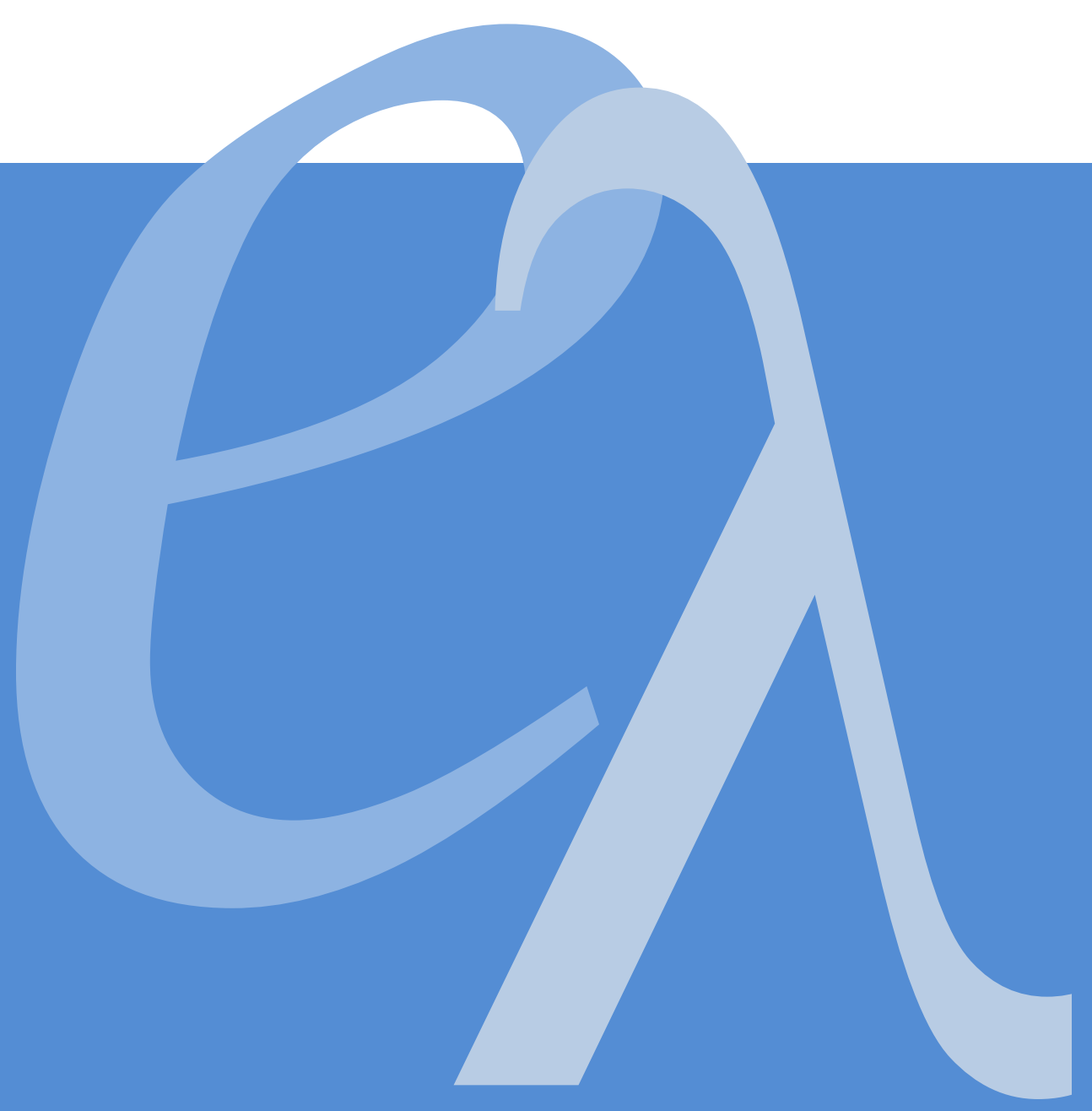




\begin{abstract}
Is everything what is happening or existing in the world determined by a causal relation and every process in nature as well as in spiritual life is thus based on given laws or is there -at least to a certain degree - coincidence, self-will or freedom?

Physicists have allways dealt with such and similar questions, which are in their principle related to the problem of validity of the causality law, or - in general determinism or indeterminism. In Max Planck times, these questions were often discussed in natural sciences and Planck himself presented various lectures on this topic. He illustrates the problem with many fictive cases as well as concrete examples and handles it in a rather amenable way.

This paper deals with Planck's view on the the law of causality, with the position of causality in physics in general (which draws the attention to the idea of "physical world-view/physikalische Weltbild“) as well as with the possible extent of compatibility between the law of causality and human freedom. Planck's constant polemics with positivism and the followers of indeterminism is thus implicitly present in my argumentation.
\end{abstract}

\title{
Abstrakt
}

Je vše, co se ve světě nějak děje či existuje, resp. každá jednotlivá událost, podmíněna příčinným vztahem a procesy $\mathrm{v}$ přírodě a $\mathrm{v}$ duchovním životě tedy probíhají na základě daných zákonů, anebo alespoň v určité míře vládne náhoda, svévole či svoboda?

Těmito a veškerými jim podobnými otázkami, vztahujícími se svou podstatou k otázce platnosti zákonu kauzality, potažmo determinismu či indeterminismu, se filozofové zabývali v podstatě odjakživa a filozofie vědy se jimi zabývá dodnes. $\mathrm{V}$ Plackově době pak představovaly zvláště $v$ exaktních prrírodních vědách velmi diskutovaný problém a sám Max Planck na toto téma přednesl několik přenášek, kde se velmi přístupným zpo̊sobem snaží dané problémy rozebírat na základě mnohých smýšlených situací i konkrétních případi̊.

Příspěvek se zabývá Planckovým pohledem na zákon kauzality obecně, postavením pojmu kauzality přímo ve fyzice, v rámci které je nutné osvětlit pojem „fyzikální světoobraz", současně pak na možnou míru slučitelnosti zákona kauzality se svobodnou lidskou vůlí. Celým př́íspěvkem pak nutně prolíná neustálá Planckova polemika s pozitivismem a př́vrženci indeterminismu. 


\section{Úvod}

Max Planck, nositel Nobelovy ceny z roku 1918 a zakladatel kvantové hypotézy, dnes patří mezi nejvýznamnější fyziky, prričemž jeho přínos tkví především v završení klasické fyziky a zahájení její nové éry 20. stol, k němuž velkou měrou přispěl prostřednictvím objevu vyzařovacího zákona absolutně černého tělesa. Tato moderní fyzika pak otevírá nové pohledy na filozofii vědy, zejména se zabývá problémem nezávislého vnějšího pozorovatele a současně též přistupuje $\mathrm{k}$ otázce svobodné vůle a kauzality. Planckovo filozofické uvažování bylo výrazně ovlivněno klasickou fyzikou, zároveň bylo též ovlivněno pozitivistickým hodnocením vědy, proti kterému neustále vystupoval a kritizoval ho. Planck si totiž v rozporu s pozitivistickými stanovisky uvědomoval, že pozornost je třeba věnovat $i$ filozofickým otázkám, jež mohou být často nazírány jakožto vědě vzdálené, přestože ve své niternosti tak pevně s exaktní vědou - fyzikou propojené. Tato potřeba filozofie $\mathrm{v}$ jeho době byla mnohými renomovanými fyziky spíše upozad'ovánu či dokonce popírána. I dnes je Planck respektován a oceňován spíše jakožto znamenitý vědec, ačkoliv z objektivního pohledu Planck dokázal souborem svých děl vytvořit z těchto dvou oblastí, $v$ jeho době vnímaných spíše jakožto obtížně slučitelných či dokonce se vylučujících, tedy vědy a filozofie, velmi kompaktní a harmonický celek. Podnětem této studie je tedy nastínění jeho filosofických myšlenek v souladu s jeho nutně neustále př́tomnou vědeckou exaktností. Pozornost je věnována především jeho pohledu na vnímání kauzality, na důvody, proč je nutné platnost kauzálního principu uvažovat ve fyzice i mimo ni, současně pak na míru slučitelnosti zákona kauzality se svobodnou lidskou vůlí, tedy otázku, jež je stále aktuálním filosofickým problémem. Cílem je vykreslení Plancka jakožto filosofa či filosofujícího vědce spíše než jakožto př́sného vědce, jenž existenci kauzality vysvětluje v souladu s nutností přijmout mimo reálného smyslového zkušenostního světa i reálný vněǰ̌ś svět fyzikálního světa a zároveň vyžaduje z určitého hlediska nutnost svobody lidské vưle.

Planck tvrdí, že lidé se v principu dělí na dvě početné skupiny - jedni, jež usilují o poznání a jež tedy cítí nezbytnost uznání př́íné kauzality též v duševní oblasti a neváhají tak obětovat vlastní vưli - a druzí, jež se nechtějí smířit s myšlenkou, že je člověk $\mathrm{v}$ podstatě snížen na úroveň bezduchého stroje pod nadvládou daných zákonů a jež chtějí při nejmenším v oblasti duševního života odepř́t platnost kauzalitě. Třetí četnou skupinu tvoří ti, jež se pohybují mezi oběma extrémy. ${ }^{1}$

\footnotetext{
1 Max PLANCK, Kausalgesetz und Willensfreiheit, Berlin: Julius Springer 1923, s. 6-7
} 


\section{Vnímání kauzality}

Pojem kauzalita je obecně znám každému člověku a jeví se ve své podstatě naprosto evidentní. Pro kauzalitu jsou uživány rozmanité definice a i sám Planck jich uvádí vícero různého stupně exaktnosti. Kauzalitu vnímá jakožto „určitý zákonitý řetězec dvou událostí, přičemž první se označuje jakožto prřčina a druhá jakožto následek“2, ale kauzální princip definuje i takto: „Cokoliv, co se stane má jednu či vícero příčin, jež dohromady nutně způsobují onu událost a opačně každá událost může být nazírána jakožto př́čina jedné či více na ně nutně následujících událostíi3 či následovně: „Jakožto kauzalitu je možné zcela obecně označit zákonnou souvislost $\mathrm{v}$ časovém sledu událostí“" ${ }^{4}$ Téměř v každé i té nejtriviálnější situaci se ke kauzalitě člověk chtě nechtě upíná. Jestliže nepřijede autobus v souladu $\mathrm{s}$ jízdním řádem, příčinu hledáme $\mathrm{v}$ dopravní zácpě, bouračce či jakékoliv jiné náhlé problémové dopravní situaci, případně indispozici řidiče. Jestliže vidíme samo se otevírající okno, raději ho následně zavřeme, nebot' na vině je nejspíše zvětšující se síla větru. Pro každý jev dokážeme najít nějakou dle nás adekvátní prríčinu, pakliže nejsme ochotni uchýlit se k přijetí faktu, že jsme se stali obětí halucinací, sugescí, mylných představivostí, či dokonce čar a kouzel. Přesto i v rámci těchto "nepřirozených“ přícin je naše představivost naprosto neomezena a jsme tak $v$ našich myšlenkách schopni uvažovat třeba i život v Matrixu ${ }^{5}$. Co už ale maximálně odporuje logice a zdravému rozumu a co si člověk nedokáže představit, je kupř́íkladu to, že část nějaké věci je větší než její celek. Skutečnost je pro Plancka pouhou částí toho, co jsou schopny obsáhnout veškeré myšlenky. Naproti tomu stojí fantazie a představivost, jež sice staví na oné skutečnosti, ale jež je též obdařena talentem vymanit se jí, díky čemuž získáváme prostor se tomuto striktně určenému světu dle naprosto jasně daných pravidel vymanit a kupř́kladu prostřednictvím umění se rozvíjet právě tak, jak si jen dokážeme představit. Nicméně co je v našem smyslu mnohem důležitější, je Planckovo tvrzení, že i věda samotná je nucena využívat fantazie, pročež uvádí př́klad Fermatova principu nejrychlejší dráhy6, jež urazí světelný paprsek mezi

\footnotetext{
2 Max PLANCK, Der Kausalbegriff in der Physik, Leipzig: Johann Ambrosius Barth 1953, s.3: „... eine gewisse gesetzmäßige Verkettung der beide Ereignisse versteht, wobei das frühere Ereignis als Ursache, das spätere als Wirkung bezeichnet wird." Vlastní překlad.

${ }^{3}$ Max PLANCK, Kausalgesetz und Willensfreiheit, Berlin: Julius Springer 1923, s. 8: "Alles, was sich ereignet, hat eine oder mehrere Ursachen, welche zusammen das betreffende Ereignis als Wirkung notwendig nach sich ziehen, und umgekehrt kann jedes Ereignis als die Ursache eines oder mehrerer mit Notwendigkeit darauf folgender Ereignisse angesehen werden." Vlastní překlad.

${ }^{4}$ Max Planck, Der Kausalbegriff in der Physik, Leipzig: Johann Ambrosius Barth 1953, s. 12: "Als Kausalitätkönnen wir ganz allgemein den gesetzlichen Zusammenhang im zeitlichen Ablauf der Ereignisse bezeichnen." Vlastní překlad.

${ }^{5}$ Matrix je americký kultovní sci-fi film popisující svět v Matrixu, rozsáhlém počítačovém systému, na který jsou připojeni lidé žijící v něm svůj virtuální život. Tito lidé si neuvědomují, že nežijí skutečný život a že v jejich mozku probíhá pouze virtuální realita.

${ }^{6}$ Fermatův princip je fyzikální tvrzení zformulované Pierre de Fermatem, jež tvrdí, že světlo se v prostoru šiří z jednoho bodu do druhého po takové dráze, aby doba potřebná k proběhnutí této dráhy nabývala nejnižší hodnoty.
} 
zářící hvězdou a lidským okem. Tento princip by totiž nebyl myslitelný v případě, že bychom neuvažovali i optické dráhy, jež ve skutečnosti neexistují a jsou tudíž kauzálně nemožné. ${ }^{7}$

Jelikož se celá fyzikální věda vtahuje k měření a experimentům a každé měření je závislé na smyslovém vnímání, veškeré pojmy fyziky jsou tak spojeny se smyslovým světem, v důsledku čehož stejně tak i každý fyzikální zákon. ${ }^{8}$ Vnímání samotné je absolutně individuální, př́íkladem může být vnímání barvy, kdy se nejedná o barvu jakožto vlastnost nějakého předmětu, ale o její svérázné vnímání individuálním člověkem. Jednoznačně individuálně vnímá člověk i všemi ostatními smysly a v případě odejmutí veškerých smyslových vnímání nějakého předmětu z něj nezbude zcela nic. Vnější svět se tak jeví jako komplex vnímání, kauzalita je pak jejich zkušeností určená pravidelnost, již musíme přijmout jakožto danou dále neanalyzovatelnou, jež ale může též každým okamžikem skončit. Uvědomění si existence vnímání druhých nicméně představuje značný problém. Tomu, že mají vjemy i ostatní lidé, pravděpodobně věříme, nicméně nemůžeme to nijak dokázat či to bezprostředně vědět. Zároveň nejsme s to nikdy přímo "prožít“ jakoukoliv jinou nežli naši vlastní zkušenost. Kdykoliv se o toto pokusíme, dojdeme pouze k závěru, jak bychom nejspíše vnímali opět jen my, kdybychom byli na místě druhého člověka. ${ }^{9}$ Nezbývá, než si vystačit s vědomím vlastním, čímž se kauzalita stává aposteriorním pravidlem, jež slučuje vlastní rozličné vjemy, nikdy si ovšem nemůžeme být jisti, zda v přšštím okamžiku nebude ono pravidlo nějakým způsobem prolomeno. Planck se tak dostává do sporu s raným pozitivismem, s nímž ostatně vede polemiku velmi často $\mathrm{v}$ mnohých oblastech, nebot' důsledný pozitivismus odmítá pojem a nutnost objektivní, tj. na individualitě badatele nezávislé fyziky a nic jiného nežli zkušenosti jednotlivých fyziků tak nemá ani $\mathrm{k}$ dispozici. Planck se ovšem domnívá, že jestliže si jakákoliv věda odejme požadavek objektivity, vynáší tím rozsudek sama sobě, nebot' základ daný fyzice pozitivismem je sice podložený, ale příliš chatrný.

\section{Reálný vnější svět, resp. fyzikální světoobraz}

Vědu je třeba zbavit nahodilosti způsobené jednotlivými lidskými jedinci. Zde Planck vyslovuje hypotézu, že „naše vlastní zkušenosti nepředstavují sám fyzikální svět, že nás spíše obeznamují o jiném světě, jenž stojí za nimi a existuje nezávisle na

${ }^{7}$ Max PLANCK, Kausalgesetz und Willensfreiheit, Berlin: Julius Springer 1923, s. 8 - 11

${ }^{8}$ Max PLANCK, Das Weltbild der neuen Physik. Leipzig: Barth 1929, s. 9

9 Ve svém slavném článku "What is it like to be a bat?“ se „nepřenositelností" zkušenosti zabývá Thomas Nagel, přičemž dochází k závěru, že bytí mezi člověkem a netopýrem je natolik rozdílné, že člověk nikdy nemůže zjistit, jaké doopravdy je oním netopýrem být. Zároveň člověk neví, jaké je to být druhým člověkem, nebot' nemůže mít jeho vlastní zkušenost. Člověk se tak může pouze vcítit do druhého člověka na základě jeho vlastní zkušenosti a do určité míry tak jen porozumět jeho pocitům. 
nás, jinými slovy, že existuje reálný vnější svět. “10, čímž v podstatě vstupuje na pole metafyzična a nachází tak nový úkol fyziky: „Fyzika nemá popisovat zkušenosti, nýbrž poznávat reálný vnější svět."11 Posledně zmíněný předpoklad spolu s následujícím: „Reálný vnější svět není bezprostředně poznatelný“12 jsou pak tedy společným východiskem pro fyzikální vědu. Planck ale nevyžaduje, aby byl cíl vědy od počátku jasně stanoven a ohraničen, nebot' cítí, že tento cíl je metafyzického charakteru a leží daleko za každou zkušeností. Kormě toho právě prostřednictvím tohoto boje se můžou vyjevovat hodnotné zkušenosti, jež dokazují, že zvolená cesta je správná a stále bližší cíli. „Ne pravda sama, ale její úspěšné nalezení podněcuje a obšt'astňuje badatele. “ 13

Dle tohoto Planckova východiska je ale nutné uvažovat potíže spojené s výzkumnými prostředky, jež přinášejí badateli zprávy právě z onoho vnějšího světa, přičemž tyto zprávy jsou stále více či méně nejisté. Ačkoli není ani nikterak pravděpodobné, že badatel zcela pochopí zákony, dle nichž se vnější svět řídí, je nutné tyto zákony alespoň předpokládat, čímž se vytváří jakýsi fyzikální světoobraz - systém pojmů a zákonů, jenž podává co možná nejidentičtější zprávy. Pozitivismus v rozporu s Planckovou představou nicméně myšlenku fyzikálního světoobrazu odmítá, „nebot' kde neexistuje žádný objekt, tam neexistuje též nic, co by mohlo být zobrazeno." 14

Úloha tohoto fyzikálního světoobrazu se vyznačuje snahou najít co možná nejtěsnější souvislost mezi reálným vnějším světem a světem smyslových zkušeností. Jedinou jeho podmínkou je jeho absolutní bezespornost, jinak je badateli ponechán volný prostor, což se ovšem může projevit určitou zvůlí a nejistotou. Badatel musí nějakým způsobem sloučit veškeré jednotlivé výsledky měření, kdy se nedokáže obejít bez určité volné spekulace. Nějaké určité obecně platné předpisy jak se rozhodnout totiž neexistují. Nestačí tak pouhé věcné znalosti - seznámení se s různými zpo̊soby měření, je třeba i tvůrčí fantazie, tedy jakési intuice, jež se projevují kupříkladu schopností pojmout dvě rozličná měření pod společným hlediskem.

\footnotetext{
${ }_{10}$ Max PLANCK, Positivismus und reale Aussenwelt, Leipzig: Akademische Verlaggesellschaft M.B.H. 1931,

s. 14: „...unsere Erlebnisse nicht selber die physikalische Welt ausmachen, dass sie vielmehr uns nur Kunde geben von einer anderer Welt, die hinter ihnen steht und die unabhängig von uns ist, mit anderen Worten, dass eine reale Außenwelt existiert" Vlastní překlad.

11 Ibid., s. 14: „sie hat nicht Erlebnisse zu beschreiben, sondern sie hat die reale Außenwelt zu erkennen." Vlastní překlad.

12 Ibid., s. 14: „Die reale Außenwelt ist nicht unmittelbar erkennbar." Vlastní překlad.

${ }^{13}$ Ibid., s. 15: „Nicht der Besitz der Wahrheit, sondern das erfolgreiche Suchen nach ihr befruchtet und beglückt den Forscher." Vlastní překlad.

${ }^{14}$ Ibid., s. 16:,,Denn wo kein Gegenstand vorhanden ist, da gibt es auch nichts was abgebildet werden kann." Vlastní překlad.
} 
Planck si uvědomuje, že vývoj vědy neprobíhá postupně prohlubováním poznatků, ale naopak velmi nárazově. Při stavbě nové hypotézy není správné užívat jen zaběhnuté představy, jejichž smysl je již jasně určen měřeními, a to $z$ těch důvodů, že každá hypotéza jakožto součást fyzikálního světoobrazu je produktem spekulujícího lidského ducha a dále proto, že neexistuje žádná fyzikální veličina bezprostředně měřená. Veškeré fyzikální veličiny získávají dle Planckova metodologického hlediska naopak význam teprve prostřednictvím významu teorií jí uděleného. I to nejpřesnější měření totiž potřebuje množství korektur odvozených právě jen z teorie. I zde se tedy Planck rozchází s metodologií pozitivismu, který teoriím přiřazuje spíše parazitní charakter. Pozitivismus naopak tvrdí, že věda se vyvíjí kumulativně na základě rozšiřování poznatků získaných prostřednictvím měření a experimentů. Na základě těchto rozšiřování poznatků pak dochází $\mathrm{k}$ proměnám teorií. ${ }^{15}$

Ideální stav pro tvorbu hypotézy představuje existence fyzikálního světoobrazu, jakožto jakéhosi samostatně utvořeného obrazu reálného světa. Platnou se posléze tato hypotéza stává ideálně tak, že z ní vyplývající teorie se vztahuje ke změřeným poznatkům. Měření tedy poskytuje stejně tak málo informací o fyzikálním světoobraze jako o reálném světě. Mnohem více naznačuje o pochodu smyslových orgánů badatele či jím užitého měřicího přístroje. „Fyzikální smysl měření tedy není bezprostředně dán, nýbrž jeho stanovení je právě tak úlohou vědy, jakožto výzkum zákonitého průběhu nějakého procesu." 16 Pokud bychom tedy tvrdili, že rozvoj co do obsahu fyzikální vědy závisí v první řadě na vývoji měřících metod, sdílíme do určité míry stanovisko spolu s pozitivismem. V souladu s pozitivistickými východisky se ale věda vyvijí způsobem, kdy dochází k neustálému navršování poznatků získaných měřeními, nebot' jestliže byl jednou poznatek uznán za součást empirické báze, zůstává její součástí i nadále nehledě na změny měřicích metod a měřicích přístrojů, případně proměn celých teorií. Nejdůležitější rozdíl nicméně spočívá $v$ pojetí, kdy dle pozitivismu vytvářejí změřené poznatky bázi, na níž je postavena celá věda, zatímco opravdová fyzika dle Plancka pojímá tato měření spíše jakožto propletený výsledek interakce procesů vnějšího světa s procesy probíhajícími $\mathrm{v}$ měřících přístrojích případně smyslových orgánech. Hlavním úkolem vědeckého výzkumu je tyto procesy rozluštit. 17 Pozitivisté nicméně předně existenci jakéhokoliv reálného vnějšího světa ve filozofickém smyslu slova pokládají za nesmyslnou. I Moritz Schlick, jehož sám Planck řadí spíše k umírněnějším

\footnotetext{
${ }^{15}$ Břetislav FAJKUS, Filosofie a metodologie vědy, Praha: Academia 2005, s. 73

${ }_{16}$ Max PLANCK, Positivismus und reale Aussenwelt, Leipzig: Akademische Verlaggesellschaft M.B.H. 1931， s. 23.:,Der physikalische Sinn einer Messung ist also nicht unmittelbar gegeben, sondern seine Feststellung ist ebensogut eine Aufgabe der Wissenschaft, wie die Forschung des gesetzlichen Ablaufs irgendeines anderen Vorganges." Vlastní překlad.

17 Ibid., s. $21-25$
} 
stoupencům pozitivismu18, ve své stati "Co znamenají výrazy „realita“ a „vnější svět" tvrdí, že veškeré fyzikální hypotézy se můžou vztahovat pouze na empirickou realitu, jestliže pod ní rozumíme to, co je poznatelné. Bylo by v podstatě rozporuplné, jestliže bychom chtěli hypoteticky předpokládat něco nepoznatelného. ${ }^{19}$ Je třeba zdůraznit, že pozitivismus existenci vnějšího světa tímto nepopírá, ale tvrdí, že stejně tak jako potvrzení, tak i popření existence vnějšího světa nesmyslné, oproti Planckovi, jenž naopak říká, že existenci tohoto světa není možné odmítnout či ignorovat, ale jeho existence může být pouze konstatována. ${ }^{20}$

Vědě tak Planck neustále podsouvá kompetenci pohybovat se na poli metafyziky, čímž tedy nutně stále odporuje stanoviskům pozitivismu, jenž tvrdí, že filozofické otázky - tedy otázky týkající se jakýchsi podkladů a předpokladů jednotlivých věd, nespadají do oblasti samotné vědy. Dle pozitivismu věda filosofii ve své podstatě nepotřebuje a odebírá jí možnost poznání světa. ${ }^{21}$ Zde se tedy Planck s předpoklady pozitivismu rozchází a tvrdí, že východiska pozitivismu vlastně znevažují význam spolupráce filozofie a odborné vědy. Je třeba si uvědomit, že stejně tak jako filozofové, tak i vědci pracují s vesměs stejnými prostředky bádání a vycházejí ze stejných východisek - tedy z denní zkušenosti a z názorů získaných vědeckým vzděláním. Planck svojí ideu nutné spolupráce vědy a filozofie ilustruje na situaci, kdy nastiňuje rozdíl mezi vědcem a filozofem analogicky ke dvěma cestujícím ve vlaku, jež pozorují krajinu. První cestující představujíc filozofa ji pozoruje prostřednictvím pohybu očí, zatímco druhý, jenž je zobrazením vědce, pozoruje krajinu prostřednictvím pevně nastaveného dalekohledu do určitého směru. Prvně zmíněný má tedy, ačkoliv velmi nejasný a rozestřený, přehled o celé krajině, zatímco druhý zpozoruje mnoho podrobností, nicméně pouze omezeného okruhu. Oba si ovšem můžou navzájem prokázat cennou službu právě formou kompilace a propletení výsledků onoho vnějšího světa, tedy světa, jenž poznává filozofie a reálného světa postihnutelného smysly prostřednictvím měřicích přístrojů. Jestliže tedy filozofie získává takto informace v rámci vědy, není možné je nijak zpochybnit. „Pokroky vědy jsou definitivní a není možné je trvale ignorovat.“22

18 Max PLANCK, „N Naturwisenschaften und reale Außenwelt.“ Naturwissenschaften, roč. 28, 1940, č. 50, s. 779

19 Moritz SCHLICK, „Kauzalita v bežnom životě a v súčasnej vede.“ In: MIHINA, F., SEDOVÁ, T., ZOUHAR, M. (eds.), Malá antológia filozofie 20. storočia. Zv. 3, Logický pozitivizmus. Bratisla: Iris 2006, s. 143

${ }^{20}$ Max PLANCK, „N Naturwisenschaften und reale Außenwelt." Naturwissenschaften, roč. 28, 1940, č. 50, s. 779

21 Břetislav FAJKUS, Filosofie a metodologie vědy, Praha: Academia 2005, s. 67

${ }^{22}$ Max PLANCK, Positivismus und reale Aussenwelt, Leipzig: Akademische Verlaggesellschaft M.B.H, 1931

s. 26: „Fortschritte der Wissenschaft sind eben endgültig und lassen sich unmöglich auf die Dauer ignorieren." Vlastní př̀eklad. 
Planck si pokládá otázku, jak tedy věda skutečně postupuje ve všech jejích jednotlivých oblastech, zda se nějakým způsobem zabývá oblastí vědomí a smyslovými vjemy, či zda jednoduše překračuje tento první zdroj poznatků a s ním vlastně celou oblast metafyziky. Je nejspíše zcela zjevné, že teprve právě v odvratu od antropocentrických či egocentrických úvah nachází počátek veškerá věda. Ovšem teprve po opuštění onoho středu vesmíru jakožto sebe samého na počátku, později i po opuštění středu vesmíru jakožto planety obývané člověkem, poté i formou co možná nejpokornějšího pozorování, nebot' cílem bylo co možná nejmenší ovlivnění pozorovaného sebou samým, mohl dosáhnout nějakých poznatků vnějšího světa. Tato východiska pak vyúst'ují v předpoklad, že pro existenci vědy je tedy nutná existence onoho na nás nezávislého světa. Cílem není celistvé přizpưsobení našich myšlenek našemu smyslovému vnímání, nýbrž celistvé oddělení fyzikálního světoobrazu od individuality tvořícího ducha. ${ }^{23}$ Nejdůležitější je ale ono uvědomění si existence těchto dvou světů, onoho vnitřního a vnějšího, a jejich následné oddělení. Jednotlivé vědy tento přechod do transcendentálna nijak nezdůvodňovaly, ač se k němu nutně uchylovaly, nebot' jinak by nemohly dosáhnout takové rychlosti v pokroku. Zároveň se ani nemusely obávat jakéhokoliv vyvrácení, prostřednictvím rozumových závěrů to, totiž ani není nikterak možné. ${ }^{24}$ Nutnost existence tohoto na našich smyslech nezávislého světa pak Planck nutně spatřuje v souladu s přijetím kauzality ve fyzice.

\section{Kauzalita ve fyzice}

Jestliže se budeme zajímat o otázku platnosti kauzality přímo ve fyzice, pak je třeba v první řadě uvážit důležitost jednotného stanoviska, v jakém smyslu je pojem kauzalita ve fyzice užíván. Vyjít můžeme z již výše zmíněného přesvědčení, že kauzalita rovná se „určitý zákonitý řetězec dvou událostí, přričemž první se označuje jakožto příčina a druhá jakožto následek“.${ }^{25}$ Planck se ale ptá, v čem vlastně spočívá onen zvláštní druh řetězce a zda existuje nějaké určité znamení, díky němuž bychom byli schopni stanovit, že jedna událost je skutečně podmíněna nějakou předešlou. Ve skutečnosti totiž dle něj neexistuje žádný takový prostředek, na základě něhož bychom byli s to jednoznačně toto potvrdit. V tomto prrípadě se se zastánci pozitivismu shoduje, nebot' i Schlick ve své stati „Kauzalita v běžném životě a v současné vědě“ tvrdí, že „jestliže hledáme kauzální spojení, které spojuje dvě události, nemůžeme najít nic jiného, nežli další událost (anebo případně několik dalších událostí). V kauzálním řetězci se dají pozorovat pouze spojení událostí a bylo

\footnotetext{
${ }^{23}$ Max PLANCK, Die Einheit des physikalischen Weltbildes, Leipzig: Verlag von S. Hirzel 1909, s. 36

${ }_{24}$ Max PLANCK, Kausalgesetz und Willensfreiheit, Berlin: Julius Springer, 1923, s. $24-28$

25 Max PLANCK, Der Kausalbegriff in der Physik, Leipzig: Johann Ambrosius Barth 1953, s. 3 „...eine gewisse gesetzmäßige Verkettung der beiden Ereignisse versteht, wobei das frühere Ereignis als Ursache, das spätere als Wirkung bezeichnet wird“ Vlastní překlad.
} 
by nesmyslem, kdybychom hledali ještě nějaký další prostředek těchto spojení. ${ }^{26}$ Schlick však současně v souladu s těmito jeho tvrzeními útočí na celou metafyziku, kterou chápe jako nesmyslnou touhu po nalezení nějakého prostředku, jenž by byl schopen vysvětlit skutečnou podmíněnost dějů. Filozofie dle něho pouze hledá nějaký "tmel“, který zaplňuje veškeré mezery mezi jednotlivými událostmi, a představuje tak právě ono "znamení", jež hledá Planck. Schlick souhlasí s tvrzením, že pokud kauzalita vůbec něčím je, pak nemůže být ničím jiným, nežli principem uspořádání. Další předpoklad, z něhož Planck vychází, je následující: „Událost je kauzálně poté podmíněna, jestliže může být s jistotou předpovězena." ${ }^{27}$ Jestliže však o kauzalitě mluvíme v souladu s výše zmíněnými předpoklady kauzality, je třeba vyvarovat se takového závěru, že jestliže něco odehrávajícího se v budoucnosti s jistotou dopředu můžeme tvrdit, mluví pak tento fakt sám o sobě pro platnost kauzality. Pro vyvrácení takového je možné uvést známý příklad sledu dne a noci, přičemž to, že s jistotou můžeme předpovědět, že po noci následuje den, neznamená, že tato noc je příčinou následujícího dne. Schlick však tuto „námitku“ proti platnosti zákona kauzality opět vyvrací jednoduše tak, že „výrazy "den“ a "noc" ve skutečnosti nejsou pojmy událostí $\mathrm{v}$ tom smyslu, v jakém je toto slovo užíváno ve vědě. Nebot' jestliže rozložíme den a noc na řadu př́rodních událostí, které tato jména zastupují, zjistíme, že postupnost těchto událostí je třeba uvažovat za velmi dobrý př́́klad ,kauzálního spojení.“" 28 Nicméně o platnosti kauzality se naopak často mluví v situacích těmto opačným, resp. v situacích, kdy nespolehlivost předpovědi je naprosto zjevná. Příkladem může být každodenní předpověd' počasí, kdy meteorologové mluví často o kauzálně determinovaných dějích probíhajících $\mathrm{v}$ atmosféře, ačkoliv jejich předpovědi jsou velmi často neúspěšné. $V$ tomto případě je možné se samozřejmě odvolávat na přilišnou komplikovanost daných objektů a atmosféry. Nicméně ani $v$ případě, že bychom tuto veškerou komplikovanost pominuli a počítali $\mathrm{s}$ ideálním případem pro předpovídání a ocitli se tak v pozici Laplaceova démona ${ }^{29}$, ani pak by dnes nebylo možné mluvit o absolutní jistotě a přesnosti předpovědi. Důvody spočívají v deterministické teorii chaosu a Lorenzově

\footnotetext{
${ }^{26}$ Moritz SCHLICK, „Kauzalita v bežnom životě a v súčasnej vede.“ In: MIHINA, F., SEDOVÁ, T., ZOUHAR, M. (eds.), Malá antológia filozofie 20. storočia. Zv. 3, Logický pozitivizmus. Bratisla: Iris 2006, s. 112

27 Ibid., s. 4

${ }^{28}$ Moritz SCHLICK, ", Kauzalita v bežnom životě a v súčasnej vede." In: MIHINA, F., SEDOVÁ, T., ZOUHAR, M. (eds.), Malá antológia filozofie 20. storočia. Zv. 3, Logický pozitivizmus. Bratisla: Iris 2006, s. 107

29 „Inteligence, jež by znala všechny působící síly v př́rodě v daném okamžiku, stejně tak jako momentální pozice všech věcí ve vesmíru, by byla schopna pochopit $\mathrm{v}$ jedné jednoduché formuli pohyb velkých těles stejně tak jako nejlehčích atomů ve světě za předpokladu, že by jeho intelekt byl schopen analyzovat všechna data. Nic by pro něho nebylo nejisté, budoucnost stejně tak jako minulost by byla př́tomna před jeho očima." Tuto hypotetickou inteligenci definoval P. S. de Laplace ve svém díle „La théorie analytique des probabilités" v roce 1820. Později byla nazvána "Laplaceovým démonem" a je spojována $v$ souvislosti s absolutně platným determinismem.
} 
objevu tzv. efektu motýlích křídel kdy „mávnutí křídel motýla v Hong-Kongu zřetelně ovlivní, jaké bude o měsíc později počasí v Londýně“. I malá nepřesnost na počátku měření může mít totiž nedozírné následky, přičemž měření není možné provést $\mathrm{s}$ absolutní přesností nikdy. Kromě toho je $\mathrm{v}$ rámci předpovědi počasí úkolem meteorologů i předpověd' klimatu, přičemž klima je představováno průměrným stavem atmosféry za dostatečně dlouhé období, nejčastěji za posledních 30 let. Předpověd' klimatu rovná se tedy předpovědi statistických charakteristik atmosféry kupříkladu na prřšší rok. V rámci teorie deterministického chaosu tak jde při nejmenším o velmi diskutabilní záležitost. ${ }^{30} \mathrm{O}$ absolutní jistotě předpovědi lze mluvit u čistě matematických výpočtů.

Podle Plancka je nutné respektovat následující skutečnost: "V žádném případě není možné přesně předpovědět fyzikální událost. “31 Takové tvrzení je ale v rozporu s jeho výchozím předpokladem o kauzální podmíněnosti události v případě, že je možné ji předpovědět. Tvrzení o nepředpověditelnosti fyzikální události podporuje stanovisko indeterminismu, který kauzalitu popírá. Indeterminismus chápe zákonitost pouze statisticky a v každém př́ípadě tak uvažuje o pouhých pravděpodobnostních zákonech vycházejících z průměrných hodnot získaných četnými pozorováními. Indeterminismus vnímá svět vystavěný výlučně na statistice, jejímž cílem je vystavět fyziku na pravděpodobnostních výpočtech.

Fyzikální vývoj vědy je nicméně postaven dle Plancka na bázi kauzality, tj. na platnosti výchozího Planckova předpokladu. Co se týče klasické dynamiky, zde se formulace zákona kauzality přibližuje přesností a precizností ideálnímu cíli, nebot' je dána jakožto určitý systém matematických rovnic, jimiž jsou určovány všechny procesy v daném fyzikálním zobrazení a jestliže jsou určeny též počáteční stavy, je možné předem vypočítat následující procesy, tedy z příčiny vyvodit následek. Co se týče teorie relativity, ta bývá někdy interpretována ve prospěch pozitivistického pojetí, navíc mnohdy jakožto protiklad transcendentální filozofie, dle Plancka ovšem zcela neprávem, nebot' podstata této teorie pro něj tkví $v$ existenci veličiny čtyřrozměrného časoprostoru - intervalu mezi dvěma nekonečně blízkými událostmi, jež má vždy stejnou hodnotu a nabývá tím na lidské vůli nezávislého transcendentálního charakteru. Planck věnuje pozornost i statistickým zákonům fyziky, které mají pouhý pravděpodobnostní charakter a připouštějí v jednotlivých případech výjimky. Jako příklad uvádí tepelnou vodivost, kdy dle druhého zákona teorie tepla přechází tepelná energie $\mathrm{z}$ teplejšího na chladnější těleso. Nicméně $\mathrm{v}$ případě výrazně malé teploty obou zahřívajících se těles může v ojedinělém místě v

\footnotetext{
30 Aleš RAIDL, "Chaos a předpověd' počasí." In: NOSEK, J. (eds.), Chaos, věda a filosofie. Praha: Filosofia 1999, s. 301-302.

31 Max PLANCK, Der Kausalbegriff in der Physik, Leipzig: Johann Ambrosius Barth 1953, s. 5. „In keinem einzigen Falle ist möglich, ein physikalisches Ereignis genau vorauszusagen." Vlastní překlad.
} 
ojedinělém časovém bodě nastat opačný přechod tepelné energie, tedy z chladnějšího na teplejší, čímž se tedy prokazuje, že onen zákon je pouze pravděpodobnostním, zatímco jeho exaktní význam platí pouze pro průměrné hodnoty velkého počtu analogických procesů. Planck tento případ přibližuje na hodu kostkou, jejíž těžiště se nenalézá ve středu, kdy je sice velmi pravděpodobné, že dopadne na předpokládanou stranu, ale není to nikterak jisté. Exaktnější výsledek je možné nalézt pouze $\mathrm{v}$ případě častého opakování hodu. Tím se tedy ukazuje, že ona předpokládaná platnost přísné kauzality je narušena zjištěným pravděpodobnostním zákonem. Nicméně podstata výše zmíněného nevězí $\mathrm{v}$ nenaplnění kauzálního zákona, nýbrž $\mathrm{v}$ dané přespř́liš malé vytř̌ibenosti pozorování pro přímý výzkum platnosti zákona kauzality. „Pokud bychom byli schopni pozorovat pohyb každé jednotlivé molekuly, pak bychom na něm potvrdili přesnou platnost dynamických zákonů." 32

Sama fyzika rozlišuje dle Plancka dva přístupy pozorování - zaprvé souhrnný makroskopický př́istup pozorovatele, při jehož uplatnění je třeba uvažovat náhodu a pravděpodobnost, zatímco onen druhý přístup - podrobný mikroskopický přístup pozorovatele - pracuje s jistotou a přísnou kauzalitou. Makroskopický pozorovatel počítá se sloučenými hodnotami a s na ně použitelnými statistickými zákony, zatímco mikroskopický badatel počítá s jednotlivými hodnotami a aplikuje na ně zcela jednoznačné dynamické zákony. Jestliže bychom tedy aplikovali mikroskopický zpo̊sob na výše zmíněný příklad vrhu kostkou, tj. určili materiál kostky, počáteční polohu, vnější účinky desky stolu, přesný odpor vzduchu v každém jednotlivém př́ípadě, byli bychom schopni vypočítat přesnou polohu a místo kostky po jejím vržení. Fyzika má nicméně každopádně snahu přeměňovat dosavadní makroskopický přístup u všech procesů molekulárního a atomárního světa na mikroskopický a statické zákony na dynamickou přísně kauzální zákonitost, tudíž je dle Plancka možné říci, že fyzika spolu s astronomií, chemií a mineralogií ve všech jejich oblastech pokládají základ platnosti přísné kauzality. ${ }^{33}$

Jestliže tedy budeme vnímat fyziku jakožto vědu postavenou na platnosti přísné kauzality, pak je ale nutné upřesnit smysl pojmu „událost" ve výchozím předpokladu o její kauzální podmíněnosti v př́ípadě, že je možné ji s jistotou předpovědět. Událost tedy nemůže představovat $v$ rámci teoretické fyziky skutečný jednotlivý měřitelný proces zahrnující též náhodné a nepředvídané události, a je tedy nutné nahradit reálný smyslový svět oním reálným vnějším světem, resp. již zmiňovaným fyzikálním světoobrazem. Ve fyzikálním světoobraze vládne dle Planckova mínění svévole myšlenkových konstrukcí, díky nimž je právě možné

32 Max PLANCK, Kausalgesetz und Willensfreiheit, Berlin: Julius Springer, 1923, s. 33: „Wären wir imstande, die Bewegung jedes einzelnen Moleküls zu verfolgen, so würden wir an ihr die genaue Gültigkeit der dynamischen Gesetze bestätigt finden." Vlastní překlad.

${ }^{33}$ Ibid., s. $33-34$ 
oprostit se od nejistot měření. $\mathrm{V}$ důsledku toho je pak možné každou jednotlivou fyzikální veličinu považovat skrze měření bud'to za bezprostředně danou či ji převést do onoho fyzikálního světa. $V$ prŕípadě prvním existuje možnost pouhé nejasné definice, $\mathrm{v}$ důsledku čehož pak není možné zobrazení určitým číslem, zatímco ve fyzikálním světě je tomu naopak a za předpokladu dodržování určitých zcela jasných předpisů je možné operovat s danými matematickými symboly.

Fyzikální světoobraz tedy neobsahuje přímo pozorovatelné veličiny, ale pouhé symboly. ${ }^{34}$ Planck však tyto symboly nechápe jakožto konvenční dohodu, nýbrž jakožto zobrazení vnějšího světa ve světoobraze v protikladu k smyslovým zobrazením. ${ }^{35}$ Součástí světoobrazu jsou pak i např. dílčí kmitání či éterické vlny, jež mohou v počátku budit dojem jen jakési př́itěže, ale právě díky těmto důležitým součástem fyzikálního světoobrazu je možné smýšlet přísný determinismus. Přesto je nutné fyzikální světoobraz uvažovat vždy jen jakožto pomocný pojem. Proces přechodu z reálného světa do fyzikálního světoobrazu tedy probíhá následovně. $V$ rámci reálného světa postihnutelného smysly $\mathrm{v}$ klasické teorii je nejprve přeměněn daný objekt smyslového světa na symbol, současně též dochází k proměně veškerých vlivů působících na tento objekt a dojde tak k celistvému převedení do fyzikálního světoobrazu. „Prostřednictvím těchto dat jsou poté navždy jednoznačně určeny vlastnosti obrazu a z diferenciálních rovnic teorie je poté možné počítat $\mathrm{s}$ absolutní přesností.“36 Planck tedy shrnuje: "Zatímco ve světě postihnutelném smysly je předpovězení nějaké události vždy zatíženo určitou nejistotou, ve fyzikálním světoobraze probíhají veškeré události dle určitých daných zákonů, jsou přísně kauzálně determinovány. Tím je prostřednictvím zavedení fyzikálního světa - a v tom právě vězí jeho význam - redukována nejistota předpovědi události světa postihnutelného smysly na nejistotu převedení události $z$ tohoto světa do světoobrazu, stejně tak jako zpětné převedení ze světoobrazu do světa postihnutelného smysly. ${ }^{37}$ Sama klasická teorie se o nejistotu př́liš nezajímala a veškerou svou pozornost věnovala spíše přísně kauzálnímu provedení procesů ve světoobraze. A ačkoliv tedy bylo možné v souladu s vývojem technologie uvažovat, že tyto nejistoty díky stále se zlepšujícím měřícím metodám postupně vymizí, bylo tomu díky Planckovi a jím zavedené konstanty ${ }^{38}$ právě naopak.

\footnotetext{
${ }^{34}$ Max PLANCK, Der Kausalbegriff in der Physik, Leipzig: Johann Ambrosius Barth 1953, s. 9

${ }^{35}$ Heinrich VOGEL, Zum philosophischen Wirken Max Planks, Berlin: Akademie Verlag 1961, s. 164

36 Max PLANCK, Der Kausalbegriff in der Physik, Leipzig: Johann Ambrosius Barth 1953, s. 9. „Durch diese Daten ist dann das Verhalten des Gebildes für alle Zeiten eindeutig bestimmt und kann aus den Differentialgleichungen der Theorie mit absoluter Genauigkeit berechnet werden." Vlastní př̌eklad.

37 Ibid., s. 10

38 Planckova konstanta h je jednou ze základních fyzikálních konstant, mající jakožto fyzikální veličina rozměr akce. Planckova konstanta byla poprvé zavedena Maxem Planckem jako konstanta vyzařovacího zákona černého tělesa. Planckova konstanta určuje danou objektivní hranici pro zjištění přesnosti, přičemž v rámci této hranice již neexistuje kauzalita, nýbrž pouhá nejistota a náhoda.
} 
Základní problém pro fyzikální světoobraz $\mathrm{v}$ klasické teorii fyziky vězí $\mathrm{v}$ Heisenbergově principu neurčitosti ${ }^{39}$ charakteristickém pro kvantovou fyziku, nebot' $\mathrm{v}$ rámci tohoto principu není $\mathrm{v}$ podstatě možné převádět dané hodnoty dvojice konjugovaných veličin z fyzikálního světoobrazu do světa postihnutelného smysly. Sám Planck vysvětluje tuto nemožnost naměřit současně přesně polohu i hybnost elektronu v souladu s kauzálním působením měřicího přístroje, jež bude vysvětleno níže. Důležité je ted' to, že jakákoliv měření hodnot, jež částice vykazují, je nutné provádět těmi nejcitlivějšími a nejjemnějšími metodami, čímž je dosahováno velmi těsného kauzálního propojení. Z toho tedy vyplývá, že určení přesné polohy částice je závislé na míře zásahu do stavu její hybnosti a současně naopak určení rychlosti částice je závislé na míre délky času. V prvním případě se tak nevyhneme narušení rychlosti částice, $\mathrm{v}$ druhém narušení její polohy v prostoru. Na základě tohoto indeterministé př́snou kauzalitu odmítají, nebot' jestliže nemůžeme získat přesně naměřené hodnoty, pak není možné ani s jistotou předpovídat, což zcela odporuje výše zmíněné skutečnosti, již je třeba v rámci platnosti kauzality nutné brát v úvahu. Možností je ale též pojmout jakoukoliv touhu po existenci přesných hodnot těchto veličin za fyzikálně nesmyslnou a př́ćcinu pak hledat ve struktuře samotného fyzikálního světoobrazu, vycházejícího z klasického pohledu na svět. Klasický pohled na svět zklamal a bylo třeba jej nahradit jiným, jenž by byl schopen zahrnout přísný determinismus včetně nespojitých hodnot fyzikálních veličin tzv. kvanta akce, jež je popsáno Planckovou konstantou. Bylo nutné také proměnit charakter prvotní součásti světoobrazu - hmotného bodu -, na základě čehož byl původní hmotný bod nahrazen systémem materiálních vln, jež jsou základními prvky onoho nového světoobrazu. V rámci toho se již hmotný bod nechová v rámci Heisenbergova systému neurčitosti, tj. jeho hybnost již není při určení polohy zcela neurčitá, ale spíše v rámci zákonů klasické mechaniky, ačkoliv všeobecně se zákony materiálních vln zásadně liší od zákonů klasické mechaniky hmotných bodů. „Důležitá je ale okolnost, že ona pro materiální vlny charakteristická funkce: vlnová funkce ${ }^{40}$ či pravděpodobnostní funkce - jméno zde nehraje žádnou roli - je zcela determinována prostřednictvím počátečních podmínek okrajových pro všechna místa a časy dle

\footnotetext{
39 Heisenbergův princip neurčitosti říká, že čím přesněji určíme jednu z kanonicky konjugovaných veličin, (nejznámějšími veličinami tohoto typu jsou poloha a hybnost základní částice $\mathrm{v}$ kvantové fyzice), tím méně přesně můžeme určit tu druhou - bez ohledu na kvalitu přístrojů. Představa $z$ klasické fyziky o předpověditelnosti chování systému, pokud známe jeho počáteční stav, je tedy nepoužitelná, nebot' počáteční stav systému nikdy nemůžeme zjistit dostatečně přesně z důvodu, že není možné dostatečně přesně zjistit oba tyto konjugované parametry

40 Vlnová funkce se užívá pro matematický popis stavu fyzikálního systému v kvantové fyzice a je možné z ní vypočítat výsledky měření provedených na systému. Na rozdíl od klasické fyziky, v které se předpokládá alespoň principiální možnost jednoznačné předpovědi měření libovolné veličiny, $\mathrm{v}$ kvantové mechanice lze obecně z vlnové funkce stanovit pouze pravděpodobnost, s jakou naměříme určitou hodnotu fyzikální veličiny, jestliže provedeme totéž měření opakovaně na několika identických systémech za stejných podmínek.
} 
zcela určitých početních pravidel, jež stojí na Schrödingerových operátorech Heisenbergových rovnic či Diracových q-číslech. " 41

Dle Plancka tedy vládne $\mathrm{v}$ rámci kvantové fyziky determinismus stejně přísně jakožto v rámci klasické fyziky, pouze za využití jiných symbolů a jiných početních pravidel, přičemž nejistota předpovědí ve smyslovém světě je redukována na nejistotu přenesení symbolů ze smyslového světa do fyzikálního světoobrazu. $Z$ toho tedy vyvozujeme, že determinismus je nutné udržet právě ve fyzikálním světoobraze. Nicméně je třeba uvědomit si rozdíl mezi klasickou fyzikou, kde bylo možné veškeré symboly (rychlost, hybnost, poloha, energie materiálního bodu) víceméně určit, zatímco $u$ vlnové funkce $v$ kvantové mechanice toto možné není už z toho důvodu, že vlnová funkce není vztahována k prostoru známému z klasické fyziky, nýbrž prostoru konfiguračnímu ${ }^{42}$. „Poté ale - a to je to důležité - neposkytuje vlnová funkce hodnoty souřadnic jako funkce času, nýbrž pouhou pravděpodobnost proto, že souřadnice mají v určitý daný čas nějaké dané hodnoty. "43 Tato námitka slouží opětovně $\mathrm{ku}$ prospěchu indeterminismu a zdá se být tentokráte potenciálně ještě úspěšnější. Nicméně může být opět vyvrácena, totiž tak, že otázka po významu určitého symbolu kvantového fyzikálního světoobrazu (např. materiální vlny) nemá opět smysl do té doby, než se stanoví, v jakém stavu se nachází měřicí přístroj určený k převedení symbolu do smyslového světa. Planck zde mluví o kauzálním působení používaného měřicího přístroje, tzn., že ona nepřesnost je alespoň částečně podmíněna tím, že hodnota měřené veličiny je určitým způsobem závislá na způsobu jejího měření. Je dokonce přesvědčen o následujícím: „Proces měření může o reálném průběhu zpravovat jen tehdy, jestliže s ním nějak kauzálně souvisí, a jestliže s ním kauzálně souvisí, pak ho také více či méně ovlivňuje a určitým způsobem narušuje, čímž pozměňuje výsledek měření." 44 Zároveň s tím je nutné si

${ }^{41}$ Max PLANCK, Der Kausalbegriff in der Physik, Leipzig: Johann Ambrosius Barth 1953, s. 13: „Wesentlich ist aber der Umstand, dass die für die Materiewellen charakteristische Funktion: die Wellenfunktion oder Wahrscheinlichfunktion - der Name tut hier nichts zur Sache - durch die Anfangsbedingungen und die Randbedingungen für alle Orte und Zeiten vollständig determiniert ist, nach ganz bestimmten Rechnungsregeln, sei es, dass man sich der Schrödeingerischen Operatoren der Heisenbergschen Matrizen oder Diracschen q-Zahlen bedient." Vlastní překlad.

42 Jako konfigurační prostor je označován vektorový prostor všech zobecněných souřadnic. Popis pohybu $\mathrm{N}$ hmotných bodů $\mathrm{v}$ tř́rozměrném prostoru může být nahrazen popisem pohybu jednoho bodu v $3 \mathrm{xN}$ rozměrném prostoru, $\mathrm{tj}$. v konfiguračním prostoru. Pojem konfiguračního prostoru může být snadno zobecněn a použit při popisu libovolného počtu bodů v prostoru libovolné dimenze.

43 Max PLANCK, Der Kausalbegriff in der Physik, Leipzig: Johann Ambrosius Barth 1953, s. 15: „Sodann aber - und das ist das Gravierende - ergibt die Wellenfunktion nicht etwa die Werte der Koordinaten als Funktionen der Zeit, sondern nund Wahrscheinlichkeit dafür, dass die Koordinaten zu einer bestimmten vorgegebenen Zeit irgendwelche vorgegebenen Werte besitzen." Vlastní překlad.

${ }^{44}$ Max PLANCK, Die Physik im Kampf um die Weltanschauung, Leipzig: Die Johann Ambrosius Barth 1945 ,

s. 14.: Der Messungsvorgang kann nur dann von dem realen Vorgang Kunde geben, wenn er mit ihm irgendwie kausal zusammenhängt, und wenn er mit irgendwie zusammenhängt, wird er ihn im allgemeinen auch mehr oder weniger beeinflussen und ihn gewisser Weise stören, wodurch das Messungsresultat verfälscht wird. Vlastní překlad. 
uvědomit, že čím užší je vztah mezi měřicím přístrojem a reálným objektem, tím větší je změna naměřené hodnoty. $V$ závislosti na míře propojení měřicího přístroje a reálného objektu je tedy možné i měnit míru narušení naměřené hodnoty, nicméně naprosto toto narušení vyloučit nelze, nebot' v př́ípadě, že by došlo k naprostému odloučení měřicího přístroje a onoho objektu, logicky bychom nemohli získat ani žádný naměřený výsledek. Indeterministé zde samozřejmě opět získávají příležitost kontrovat tím způsobem, že jakékoliv zkoumání tohoto kauzálního pusobení měřicího přístroje $\mathrm{v}$ podstatě ztrácí smysl, nebot' nepřesnost naměřených hodnot by se tak s každým dalším zkoumáním, tj. další naměřenou nepřesností, jen zvyšovala. Planck ale nejistotu předpovězení události, potažmo tedy možné hranice poznání nespojuje s nejistotou měření, nebot' „naštěstí vlastníme měřicí prrístroj, jenž není spojen s žádnou hranicí přesnosti, a tím je tok našich myšlenek. Myšlenky jsou křehčí nežli atomy a elektrony, v myšlenkách můžeme atomové jádro rozštěpit stejně tak jednoduše jako překonat kosmickou vzdálenost miliónů světelných let." 45

Základním kamenem, jenž tedy podporuje stanoviska indeterministů, je dle Plancka fakt, že vlnová funkce v kvantové fyzice je pouhou pravděpodobnostní veličinou, zatímco deterministé považují vlnovou funkci za pravděpodobnostní veličinu pouze do té doby, kdy je brán v potaz měřicí př́istroj, jímž je vlna měřena, zatímco se pokouší hledat zákonité vztahy mezi vlastnostmi vlnové funkce a procesy v měřicím přístroji. To je možné jedině tak, že nejen vlnovou funkci a měřicí přístroj, ale i veškeré další pomůcky nutné $\mathrm{k}$ experimentům pojmeme jako uzavřený jediný celek a přeneseme do fyzikálního světoobrazu. Přímá zkouška sice není možná, čímž se problém opět jen komplikuje a zavdávají se tak příčiny pro podporu stanovisek indeterminismu. Nicméně nic nebrání tomu, vytvářet na základě vnitřních procesů ve fyzikálním světoobraze hypotézy, jejichž důsledky bude možné testovat $\mathrm{v}$ reálném smyslovém světě.

Provedení přísně kauzálního postupu není ani z pohledu moderní fyziky naprosto vyloučena, ačkoliv kauzalitu není možné dokázat ani a priori ani aposteriori. Je důležité si ale uvědomit, že kauzalita je přirozeně nezávislá na člověku, jenž ji uvažuje. Nicméně přesto ji člověk napojil na lidský intelekt, resp. na schopnost předpovídat událost. Planck říká, že „jsme si provedení deterministického přístupu vynutili jen tím, že jsme na místo bezprostředně daného smyslového světa dosadili fyzikální světoobraz, tedy výtvor lidské fantazie provizorního a proměnlivého charakteru. "46 Kauzalitu tak vnímá jakožto transcendentální na člověku nezávislou,

${ }^{45}$ Max PLANCK, Determinismus oder Indeterminismus? Johann Ambrosius Barth 1953, s. 24: „...zum Glück besitzen wie ein Messungsinstrument, das an keinerlei Grenzen der Feinheit gebunden ist, das ist der FLug unserer Gedanken. Gedanken sind feiner als Atome und Elektronen, in Gedanken vermögen wie ebenso leicht einen Atomkern zu spalten wie eine kosmische Distanz von Millionen Lichtjahren zu überspringen." Vlastní př̀eklad.

${ }^{46}$ Max PLANCK, Der Kausalbegriff in der Physik, Leipzig: Johann Ambrosius Barth 1953, s. 20: „... wir haben auch die Durchführung der deterministischen Betrachtugsweise nur dadurch erzwingen 
existující ve vnějším reálném světě, vždy platnou. Rozlišením na platnost a realizovatelnost kauzality si Planck vytváří podmínky pro uznání existence svobodné lidské vůle. ${ }^{47}$

\section{Svobodná vůle}

Jestliže je řeč o přrísné kauzalitě, pak je třeba též zmínit otázku existence svobodné vůle, jež se tedy staví logicky př́ísné kauzalitě na odpor a nastínit způsob, jak s tímto rozporem Planck vyrovnává. K rozřešení dilematu, zda je lidská vưle svobodná, či naopak podřízena přísné kauzalitě, byly provedeny mnohé pokusy. Argument svobodné vůle byl dokonce využit jako zdůvodnění hypotézy pouhého statistického př́stupu ke skutečnosti, což sám Planck ovšem nijak nepodporoval. Dle něj by v prrípadě platnosti takové hypotézy byla lidská vưle degradována na jakýsi orgán slepé náhody. Podle něho otázka svobodné vưle v podstatě s protikladem statistické a kauzální fyziky vlastně vůbec nesouvisí.

Planck navíc upozorňuje, že otázka, zda je lidská vưle svobodná či př́isně determinována, je navíc postavena na logicky nepř́ípustné disjunkci. Ani jedna možnost totiž nevylučuje druhou. Připuštění možnosti kauzálně determinované lidské vůle též obsahuje předpoklad předvídatelnosti celkového lidského jednání včetně všech jeho motivů. Touto schopností by nicméně opět vládl pouze hypotetický Laplaceův démon, v Planckově terminologii jakési „božské oko“, jež by dokonale prohlédlo vědomí i podvědomí, veškeré fyzické i duševní vlastnosti člověka, jehož vůle by byla podřízena přísné kauzalitě. Z toho vyplývá, že není možné podrobit determinovanost duševních procesů jakémukoliv pokusu, nebot' patří do oblasti metafyziky, stejně tak jako otázka existence fyzikálního světoobrazu, ačkoli oboje není možné logicky popřít.

Pokud tvrdíme, že lidská vưle je svobodná, pak to znamená, že je každý člověk schopen rozhodnout se dle svého vlastního uvážení z několika možností jednání pro nějakou konkrétní možnost, což nikterak nestojí v rozporu s předcházejícími tvrzeními. Onen rozpor by nastal teprve tehdy, jestliže by člověk dokázal sám sebe prohlédnout oním Laplaceovým démonem, nebot' pak by mohl předvídat na základě kauzality své vlastní svévolné jednání, čímž by jeho vưle přestala být svobodnou. Tento př́ipad je nicméně logicky vyloučen. „Nebot' i to nejpřesnější oko se dokáže prohlédnout právě tak málo jako dokáže nějaký nástroj sám sebe opracovat." 48 Není

\footnotetext{
können, dass wie an die Stelle der unmittelbar gegebenen Sinnenwelt das physikalische Weltbild setzen, also eine Schöpfung menschlicher Einbildungskraft von provisorischem und wandelbarem Charakter." Vlastní překlad.

${ }^{47}$ Heinrich VOGEL, Zum philosophischen Wirken Max Planks, Berlin: Akademie Verlag 1961, s. 179

${ }^{48}$ Max PLANCK, Positivismus und reale Aussenwelt, Leipzig: Akademische Verlaggesellschaft M.B.H, 1931,
} 
tudíž možné nějak ztotožnit subjekt s objektem poznávací činnosti a zároveň je tedy od počátku nesmyslné ptát se po platnosti zákona kauzálnosti v souvislosti se svévolnými činy.

V principu je tedy možné uplatnit kauzalitu na veškeré procesy okolního hmotného i duchovního světa skrze svou inteligenci do té míry, pokud není ovlivněna ona sama tímto uplatněním - ne tedy na vlastní myšlenky a jednání, at' už současné či budoucí. „Ony [myšlenky] jsou jediným objektem, jenž abstraktně zbavuje v principu sám sebe nátlaku kauzálnosti, jsou ovšem právě tím jediným objektem, jenž si vytváří své nejcennější a osobité vlastnictví a na jehož náležité správě závisí pokoj a blaho." ${ }^{49}$

Otázka existence svobodné vůle je i jedním z problémů týkajících se rozlišení zdánlivé kontra opravdové problémy vědy. Důležité pro správné uplatnění metody výzkumu obecně je zachování absolutní neovlivnitelnosti tohoto výzkumného procesu. A to, co platí pro výzkumné procesy fyzikální, platí dle Plancka současně i pro mentální stavy a procesy. Je tedy jednou ze základních zásad experimentální psychologie, že $\mathrm{v}$ případě, kdy zkoumaná osoba ví, že je pozorována, může být právě toto pozorování jedním z významných zdrojů následných chyb. Samotné pozorování vůle je vlastně mentální proces, čímž by tedy mohla být vlastní vůle výrazně ovlivněna a jediný zpo̊sob, jak je možné se této situaci vyvarovat, tkví v možnosti pozorování vůle někoho jiného bez jeho vědomí. „Proto je nepřípustné pozorovat vlastní vůli z hlediska vlastního já, a sice stejně tak současnou jakož i budoucí, neb ta je současně naprosto podmíněna. Naopak nestojí nic v cestě zkoumat vědecky z hlediska já hnutí mysli v minulosti. “50 Mentální procesy z minulosti totiž není možné dodatečně nijak ovlivnit. Na základě výše zmíněného tak Planck rozlišuje mezi vnějším hlediskem pozorování vůle, jež nemůže být nijak narušeno a je tedy vhodné ke zkoumání vůle, přičemž zahrnuje výzkum cizí vůle a výzkum vlastní vůle v minulosti - a vnitřním hlediskem, jež výzkum vůle vždy naruší, je pro něj tedy nevhodné a zahrnuje zkoumání aktuálních a budoucích procesů vůle vlastního já.

s. 32: „Denn auch das feinste Auge vermag sich ebensowenig selber zu durchschauen als wie irgendein Werkzeug sich selber bearbeiten kann." Vlastní překlad.

49 Max PLANCK, Positivismus und reale Aussenwelt, Leipzig: Akademische Verlaggesellschaft M.B.H, 1931,

s. 33: „Diese sind das einzige Objekt, welches sich für ihn begrifflicherweise prinzipiell dem Zwang des Kausalgesetzes entzieht, freilich gerade dasjenige Objekt, welches seinen kostbarsten und eigensten Besitz ausmacht und von dessen richtiger Verwaltung sein Friede und seine Glück abhängt." Vlastní překlad.

50 Max PLANCK, Scheinprobleme der Wissenschaft, Leipzig: Barth 1953, s. 22: „Daher ist es unzulässig, vom Standpunkt des eigenen Ich aus den eigenen Willen zu betrachten, und zwar sowohl den gegenwärtigen als auch den zukünftigen Willen, den dieser wird durch den gegewärtigen Willen unbedingt. Dagegen steht nicht im Wege, eine Willensregung des vergangenen Ich wissenschaftlich zu betrachten." Vlastní překlad. 
Z reality je nám blízké, že právě z onoho vnějšího hlediska předpokládáme ve styku s lidmi vždy určité motivy jejich mluvy či jednání, tedy kauzální podřizenost svobodné vůle. Co se týče vnitřního hlediska, zde věda selhává a jediným poznávacím zdrojem se stává vlastní vědomí, jež nás bezprostředně informuje, jak a proč zásobujeme naše myšlenky a vůli. Planck upozorňuje na to, že zde nejsme nijakým způsobem brzděni okolnostmi, nýbrž se jedná o jakýsi směr smýšlení vůle, s níž volně nakládáme, a to je tedy právě ta jediná bezprostřední svoboda. Planck shrnuje: „Vůle zkoumána zvenčí je kauzálně determinována, zevnitř je svobodná.", z čehož tedy jasně vyplývá i daná pouhá zdánlivost problému lidské vůle, jenž byl postaven pouze na nepozornosti stanovení a následného dodržení rozlišení dvou výše zmíněných stanovisek. ${ }^{51}$

Jediná oblast, která je a navždy musí zůstat jak přírodnímu tak duchovnímu světu zcela nepř́istupná je oblast „vlastního já“ - „Tento nepatrný bod [...] v rozsahu světa a přece naproti tomu celý svět, svět, jenž objímá všechny naše pocity, vůli a myšlení, svět, jenž v sobě ukrývá vedle nejhlubšího zármutku nejvyšší blaženost, jediné vlastnictví, jež nám nemůže vyrvat žádná moc osudu a jež jednou vydáme jen spolu s naším životem." 52 Můžeme ovšem samozřejmě pochopit i každou naši prožitou zkušenost jakožto kauzálně danou, k tomu by ale bylo nutné dosáhnout pozice Laplaceova démona. Teprve pak by byl splněn předpoklad určitého odstupu mezi zkoumajícím subjektem a zkoumaným objektem, jenž je nutný pro realizovatelnost kauzálního provedení. Čeho je ale absolutně nutné se vyvarovat, je rezignace na naše vlastní vědomí. „Zde je tedy to místo, kde začíná svobodná vůle a trvá na něm, aniž by se nechala někdy vypudit. "53 Tento v podstatě pouhý bod, jenž je zákona kauzality oproštěn, ale není možné šiřit též na další oblasti, čímž je myšleno především přenesení na ostatní lidi. Ačkoli se nikdy nemůžeme ocitnout v oné pozici Laplaceova démona, neustále jsme s to prohlédnout motivy druhého člověka mnohem lépe, nežli on sám ty své, v rámci čehož můžeme soudit i jeho vůli jakožto kauzálně determinovanou. 54

\footnotetext{
51 Max PLANCK, Scheinprobleme der Wissenschaft, Leipzig: Barth 1953, s. 21 -25

52 Max PLANCK, Kausalgesetz und Willensfreiheit, Berlin: Julius Springer 1923, s. 45: „Ein winziger Punkt [wie ich sagte] im Weltbereich, und doch wiederum eine ganze Welt, die Welt, die unser gesamtes Fühlen, Wollen und Denken umfaßt, die Welt, die neben dem tiefsten Leid die höchste Glückseligkeit in sich birgt, das einzige Besitztum, das uns keine Schicksalmacht entreißen kann, und das wir nur mit unserm Leben selber dereinst preisgeben." Vlastní překlad.

53 Ibid., s. 46: „Hier ist also die Stelle, wo die Willensfreiheit einsetzt und ihren Platz behauptet, ohne sich durch irgend etwas verdrängen zu lassen." Vlastní překlad.

54 Ibid., s. $42-47$
} 


\section{Závěr}

Ústředními pojmy všech Planckových filozofických statí jsou kauzalita a svobodná vůle. Planck si je vědom toho, že o platnosti kauzality není možné rozhodnout nijakým čistě logickým způsobem a snaží se tedy tuto závažnou, stále aktuální otázku, osvětlovat pomocí rozborů mnoha smyšlených situací, svá stanoviska pak dokazuje na mnohých př́kladech vycházejících z praktického života. Všemi Planckovými filozofickými díly prostupuje jeho hluboká kritika pozitivismu, at' př́má či nepř́má, ačkoliv v roce 1940 Planck púše: „Sám jsem se ještě před 50 lety počítal $\mathrm{k}$ přesvědčeným pozitivistům, toto období někdy zakusí každý kriticky způsobilý vědec a setrvá v něm kratší či delší čas. “55 S pozitivistickými stanovisky se totiž Planck později rozchází $\mathrm{v}$ mnohých klíčových oblastech, nejvýrazněji pak v otázce existence reálného vnějšího světa, teorie poznání i v otázkách vztahujících se k platnosti kauzality.

Zatímco Planck vychází přinejmenším v celé oblasti vědy z platnosti kauzálního principu, pozitivismus vnímá kauzalitu spíše jakožto lidský produkt, čímž tedy mizí i jakákoliv nejistota s ní spojena. Ačkoliv silnou stránku pozitivismu Planck spatřuje v jeho neopomíjení žádného lidského zdroje, tj. žádné prožité zkušenosti, současně $\mathrm{v}$ tomto spatřuje i jeho jistou potíž, totiž že pozitivismus zajímají v podstatě pouhé zkušenosti, po jejichž odebrání nezůstává v podstatě zhola nic, co by mohlo být zkoumáno. Další zmiňovanou potíží, jež Planck spatřuje v požadavcích pozitivismu, je nutnost rozlišení vnímání vlastních a ostatních. S tím souvisí i Planckův hluboký nesouhlas s pozitivistickým požadavkem odejmutí objektivity, nebot' Planck vyžaduje, aby věda byla zbavena jakýchkoliv nahodilosti. Tím, že takto v rámci pozitivismu dochází podle Plancka k popření jakékoliv objektivní vědy, tak pozitivismus nemůže vytvářet ani nijakou bázi exaktních věd, resp. fyziky. Planck v souvislosti s tím vyslovuje odvážnou hypotézu, kdy vstupuje na pole metafyziky, a dostává se tak opět do konfliktu s pozitivismem, totiž že zkušenosti nás pouze obeznamují o vnějším světě a úkolem fyziky je tento svět poznávat, zatímco pozitivismus ve své rané fázi spatřuje hlavní úkol vědy v popisu komplexu vjemů. Dle Plancka je pak nutné vytvořit jakýsi fyzikální světoobraz, přičemž do tohoto procesu je nezbytné zahrnout i potřebu existence lidské fantazie a představivosti. Planck se tak s pozitivismem rozchází už v samotném základu, kdy pozitivismus jakoukoliv metafyziku odmítá a filozofii odebírá možnost poznání světa. Planck naopak tvrdí, že poslání vědy a filozofie je identické a věda s filozofií by měla

\footnotetext{
55 Max Planck, „N Naturwisenschaften und reale Außenwelt.“ Naturwissenschaften, roč. 28, 1940, č. 50, s. 779:

„Ich selber habe ich mich noch vor 50 Jahren zu den überzeugten Positivisten gerechnet; diese Periode macht wohl jeder etwas kritisch veranlagte Forscher einmal durch und verharrt in ihr eine kürzere oder längere Zeit." Vlastní překlad.
} 
spolupracovat, nebot' jedna druhé mohou svým pohledem na svět poskytnout cennou službu v zprostředkování jiného pohledu na reálný svět.

Planck tvrdí, že samotná fyzika staví na základě platnosti přísné kauzality a jestliže se někdy jeví situace opačně, pak je to zpơsobeno pouhým nedostatkem informací o zkoumaném jevu. Co se týče podmínění svobody lidské vưle, tam je otázka platnosti kauzality obtížnější. Planck uznává, že veškerá mysl a lidská vůle může být prohlédnuta a tím podřízena kauzalitě, ale ne vlastní mysl sebou samým. Na základě toho je tedy nutné rozlišovat mezi platností kauzality - kdy je platná díky své transcendentalitě vždy, a realizovatelností kauzality - kdy je realizovatelná pouze za podmínky uplatnění jakéhosi mikroskopického pozorovatele vůči zkoumané mysli a jedině tak by bylo možné prohlédnout své vlastní motivy spouštějící kauzalitu. V Planckově podání je tedy vnímání kauzality naprosto slučitelné s uznáním svobody vůle. Vưči cizí mysli má dle Plancka člověk možnost do určité míry se oním mikroskopickým pozorovatelem stát a jeho mysl tak kauzálně prohlédnout. Současně také Planck uvádí, že je vlastně nutné vzdát se souzení sebe jakožto kauzálně podmíněného, nebot' jedině pak je možné oddávat se již zmiňované fantazii. Zde tak dochází ke značnému rozporu, nebot' z pohledu druhé osoby je naše vůle Planckovým pohledem zcela kauzálně podmíněna, zatímco z našeho vlastního pohledu ji takto vnímat nesmíme. Planck tedy člověka nutí se nějak „cítit“, ačkoliv on sám dobře ví, že skutečnost je naprosto protichůdná. V rámci otázky zkoumání svobodné vůle Planck naráží i na nutnost rozlišení vědeckých problémů na skutečné. Problém svobodné vůle pak kvalifikuje jakožto zdánlivý s poukazem na jádro zdánlivosti problému spočívající právě $\mathrm{v}$ nedodržení rozlišení těchto zmíněných dvou stanovisek, totiž že vưle zkoumána zvenčí je kauzálně podmíněná, zatímco zevnitř je svobodná.

Planck si uvědomoval, že realita kolem nás je kauzální a situace a procesy probíhající kolem nás jsou tedy založeny na vztahu př́ičinnosti, tím spíše procesy probíhající ve fyzice. Naproti tomu je však zřejmé, že nějakým zpơsobem člověk není schopen rezignovat na náhodu a pravděpodobnost, ačkoliv je samozřejmě možné, vysvětlit si náhodu na základě nedostatku znalostí o onom náhodném jevu, jak činí právě Planck. Podobně můžeme též nahlížet určité náhodné chování našich bližních, resp. vycházet $z$ toho, že pokud se nám nějaký jejich čin jeví jakožto nesmyslný či zcela nahodilý, nemáme zřejmě dostatek informací o motivech jeho jednání či neznáme dokonale jeho charakter, aktuální náladu, situaci, případně mnoho dalších jevů, jež mohly stát příčinnou právě tomu jeho pro nás nesmyslného či nahodilého jednání. Téměř vše odehrávající se kolem nás je tedy možné dříve či později, více či méně prohlédnout jakožto kauzálně podmíněné a přesto člověk věří, že on sám kauzalitě podřízen není. 
A to je tedy i místo, kde je s Planckem pravděpodobně nevyhnutelné než souhlasit. Cítíme, že naše vlastní svobodné vědomí je v rozporu s klasickým pojetím determinismu. Nezdá se nám, že by všechny směry vůle a to nejen vůle někoho druhého, ale i naší vlastní, byly podřízeny přísné kauzalitě. Je sice nejspíše pravda, že kdyby i naše vědomí podléhalo tomuto absolutnímu determinismu, neměli bychom zatím př́ležitost to zjistit, nebot' vědomí je uloženo kdesi hluboko uvnitř nás samých, kam mnohokrát ani člověk sám nedohlédne. Požadavek svobodné vlastní vůle je nutný už z toho důvodu, že pokud by člověk neměl možnost volby rozhodnout se, nemohl by posléze být nikterak zodpovědný ani za své jednotlivé činy. Zároveň by pak tudíž nemohl podléhat pochvale či trestu, čímž by bylo nutné rezignovat na jakékoliv mravní a etické požadavky. Jakékoliv souzení druhého by se posléze vlastně samo stalo určitým přečinem. Sám člověk by bez svobodné vůle ztratil prožitek týkající se dobrého či špatného svědomí, čímž by zároveň utrpěla i jeho samotná důstojnost a člověk by pomalu přestával být člověkem. Planck samotný tedy varuje před odvoláváním se na přírodní zákon kauzality, co se vlastní vůle týče, kdy dle něj po jejím př́ípadném podlehnutí jen dokazuje, že není s to kočírovat svou vlastní vůli, potažmo tedy celý život.

Pro tyto všechny výše zmíněné důvody je nutné ocenit, že i tak přísný vědec, jakým byl Planck, se neváhal velmi často odvážit k vkročení na pole metafyziky, at' už voblasti svobodné vůle, jím často zmiňované potřeby fantazie či nutnosti existence vnějšího světa, resp. fyzikálního světoobrazu. 


\section{Bibliography}

FAJKUS, Břetislav. Filosofie a metodologie vědy. Praha: Academia 2005

LAPLACE, Pierre-Simon. Théorie Analytique des Probabilités. Vol. I. = Introduction. Essai philosophique sur les probabilités. Paris: Jacques Gabay 1995

NAGEL, Ernst. „What Is It Like to Be a Bat?" The Philosophical Review, Vol. 83, 1974, No. 4, s. 435 - 450

PLANCK, Max. Determinismus oder Indeterminismus. Leipizig: Johann Ambrosius Barth Verlag 1953

PLANCK, Max. Der Kausalbegriff in der Physik. Leipzig: Johann Ambrosius Barth Verlag 1953

PLANCK, Max. Die Einheit des physikalischen Weltbildes. Leipzig: Verlag von S. Hirzel 1909

PLANCK, Max. Die Physik im Kampf um die Weltanschauung. Leipzig: Johann Ambrosius Barth Verlag 1945.

PLANCK, Max. Kausalgesetz und Willensfreiheit. Berlin: Julius Springer 1923.

PLANCK, Max. „Naturwisenschaften und reale Außenwelt." Naturwissenschaften, roč. 28,1940

PLANCK, Max. Positivismus und reale Aussenwelt. Leipzig: Akademische Verlaggesellschaft M.B.H, 1931.

PLANCK, Max. Scheinprobleme der Wissenschaft. Leipzig: Johann Ambrosius Barth Verlag 1953.

PLANCK, Max. Das Weltbild der neuen Physik. Leipzig: Johann Ambrosius Barth Verlag 1929.

RAIDL, Aleš. "Chaos a předpověd' počasí.“ In: NOSEK, J. (eds.), Chaos, věda a filosofie. Praha: Filosofia 1999

SCHLICK, Moritz. „ Kauzalita v bežnom životě a v súčasnej vede.“ In: MIHINA, F., SEDOVÁ, T., ZOUHAR, M. (eds.), Malá antológia filozofie 20. storočia. Zv. 3, Logický pozitivizmus. Bratisla: Iris 2006 
VOGEL, Heinrich. Zum philosophischen Wirken Max Planks. Berlin: Akademie Verlag 1961 


\section{E-LOGOS}

ELECTRONIC JOURNAL FOR PHILOSOPHY

Ročník/Year: 2011 (vychází průběžně/ published continuously)

Místo vydání/Place of edition: Praha

ISSN 1211-0442

Vydává/Publisher:

Vysoká škola ekonomická v Praze / University of Economics, Prague

nám. W. Churchilla 4

Czech Republic

13067 Praha 3

IČ: 61384399

Web: http://e-logos.vse.cz

Redakce a technické informace/Editorial staff and technical information:

Miroslav Vacura

vacuram@vse.cz

Redakční rada/Board of editors:

Ladislav Benyovszky (FHS UK Praha, Czech Republic)

Ivan Blecha (FF UP Olomouc, Czech Republic)

Martin Hemelík (VŠP Jihlava, Czech Republic)

Angelo Marocco (Pontifical Athenaeum Regina Apostolorum, Rome, Italy)

Jozef Kelemen (FPF SU Opava, Czech Republic)

Daniel Kroupa (ZU Plzeň, Czech Republic)

Vladimír Kvasnička (FIIT STU Bratislava, Slovak Republic)

Jaroslav Novotný (FHS UK Praha, Czech Republic)

Jakub Novotný (VŠP Jihlava, Czech Republic)

Ján Pavlík (editor-in-chief) (VŠE Praha, Czech Republic)

Karel Pstružina (VŠE Praha, Czech Republic)

Miroslav Vacura (executive editor) (VŠE Praha, Czech Republic) 